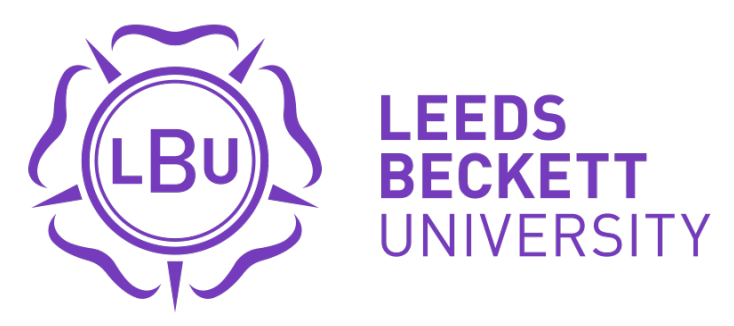

Citation:

Thomas, R (2020) Affective subjectivation or moral ambivalence? Constraints on the promotion of sustainable tourism by academic researchers. Journal of Sustainable Tourism. ISSN 0966-9582 DOI: https://doi.org/10.1080/09669582.2020.1770262

Link to Leeds Beckett Repository record:

https://eprints.leedsbeckett.ac.uk/id/eprint/6757/

Document Version:

Article (Accepted Version)

This is an Accepted Manuscript of an article published by Taylor \& Francis in Journal of Sustainable Tourism on 25 May 2020, available online: http://www.tandfonline.com/10.1080/09669582.2020.1770262

The aim of the Leeds Beckett Repository is to provide open access to our research, as required by funder policies and permitted by publishers and copyright law.

The Leeds Beckett repository holds a wide range of publications, each of which has been checked for copyright and the relevant embargo period has been applied by the Research Services team.

We operate on a standard take-down policy. If you are the author or publisher of an output and you would like it removed from the repository, please contact us and we will investigate on a case-by-case basis.

Each thesis in the repository has been cleared where necessary by the author for third party copyright. If you would like a thesis to be removed from the repository or believe there is an issue with copyright, please contact us on openaccess@leedsbeckett.ac.uk and we will investigate on a case-by-case basis. 


\title{
Affective subjectivation or moral ambivalence? Constraints on the promotion of sustainable tourism by academic researchers
}

\section{Rhodri Thomas}

School of Events, Tourism and Hospitality Management, Leeds Beckett University, Leeds, LS6 3QN, UK

\section{r.thomas@leedsbeckett.ac.uk}

\begin{abstract}
This paper examines an increasingly pervasive aspect of neoliberal research funding regimes, namely the expectation that academic research should influence non-academic policy and practice. More specifically, it explores the reaction of British academic researchers with an interest in sustainable tourism to what has become known as the impact agenda. How do they conceptualise impact? Do they moralise impact (perhaps in relation to the limits of their expertise or the veracity of their claims)? Does this aspect of research policy affect their approach to academic work? The findings of a qualitative study reveal a constituency of academic researchers primarily concerned with their own performativity. There is seemingly limited moral framing of research impact and a suggestion of moral hypocrisy. Widespread affective subjectivation provides a plausible explanation for current academic behaviour. The paper concludes by arguing that without a collective re-thinking of how sustainable tourism research might gain influence beyond academia, it is probable that performative practices will continue to characterise academic responses to the impact agenda.
\end{abstract}

$\begin{array}{llll}\text { Keywords: } & \text { research impact } & \text { research evaluation } & \text { moralising research } \\ & \text { Neoliberal university } & \text { academic activism } & \text { research leadership }\end{array}$

\section{Introduction}

Picture these scenes:

Scene one: We are at the World Travel Market (WTM). There are more than 50000 people milling around over three days. Some are key players: decision-makers, brokers, investors. This is big business. The deals struck here will influence what is on offer to consumers next season. There is great excitement at the prospect of the multi-billion dollars' worth of transactions exceeding last year's record. But WTM is not all about being commercial. There is room for reflection about how the world might be improved via tourism. Although the aims of World Responsible Tourism Day (WRTD) are not defined precisely, they are evidently about promoting social justice and 
environmental improvement. Enlightened business leaders celebrate the good work of far-sighted companies. Academics, some fawning - none critical, join the celebration and contribute to the back slapping. There are advantages to be gained if academics can get in on the act even if they are not seen as the experts.

Scene two: A national news programme is featuring a story about 'overtourism' in Venice, Italy. A similar programme was broadcast recently about Barcelona, Spain. Two experts are offering their perspectives eloquently. One, a tour operator, is radical, arguing for fewer flights, higher taxes and a more responsible approach to travel. Academics do not feature in these programmes.

Scene three: A newspaper article is critical of airbnb's effect on communities. The concerns of local residents are reported and there is a comment from a senior academic. Although she speaks authoritatively about the denigration of social relationships precipitated by the platform, no evidence is brought to bear. This is not surprising as her expertise lies elsewhere.

These imagined vignettes will resonate with tourism academics who work in systems of higher education that adopt (non-academic) 'impact' as a measure of research performance. Although the UK is probably at the forefront of such approaches - impact now accounts for 25 per cent of the forthcoming official evaluation of research (REF, 2021) - similar language inflects research policy in many other parts of the world (Brauer, Dymitrow, \& Tribe, 2019). 'Impact' is defined in the UK as 'an effect on, change or benefit to the economy, society, culture, public policy or services, health, the environment or quality of life, beyond academia' (emphasis added) and applies to all disciplines and fields of study (https://impact.ref.ac.uk/casestudies/FAQ.aspx). Similarly nebulous statements are made by officials in other countries where impact features in research performance evaluation (Airey, Tribe \& Benckendorff, 2015).

The appeal of impact to those funding research prompts debate about the purpose of academic research, the role of universities and the resulting behaviour of academics; it is criticised by some (e.g. Sayer, 2015) and commended by others (e.g. Bastow et a. 2014). A growing emphasis on impact articulates comfortably, prima facie at least, with sub-fields such as sustainable tourism because researchers generally adopt a normative-analytical approach to their work i.e. they are concerned to improve the world, as they see it, via their research and its utilisation.

Since its inception, the Journal of Sustainable Tourism (JoST) has taken more than a passing interest in impact. Its first editorial emphasised the need to 'foster research and practice... to help develop both a theoretical base for the subject and reliable empirical evidence of its results and impacts' (cited in Bramwell \& Lane, 2002: 2-3). Indeed, its promotion of sustainable tourism is - perhaps - its most prominent mark of distinction. In this light, academic advocacy is seen as highly desirable, as a more recent editorial confirms (Bramwell, Higham, Land \& Miller, 2016: 2):

Recognition of the importance of advocacy which is based on rigorous, critical and reflexive research is an especially important position for a journal that addresses the contentious issues of sustainable tourism... In order to reduce pressure on the environment, societies, heritage and culture, while spreading the benefits equitably, including between hosts and guests...

Further affirmation of the journal's commitment to impact appeared recently (Font, Higham, Miller \& Pourfakhimi, 2019). Such declarations are not unique to tourism studies. A Times Higher Education report highlighted a new fervour for impact among the world's leading medical journals (23 $3^{\text {rd }}$ January, 2020), for example. 
This paper investigates the reaction of academic researchers with an interest in sustainable tourism to what is becoming an international research policy priority (Airey, Tribe \& Benckendorff, 2015). How do academic researchers conceptualise impact? Do they moralise impact (perhaps in relation to the limits of their expertise or the veracity of their claims)? Does this aspect of research policy affect their approach to academic work? Thus, unlike those who focus on institutional-community approaches to research collaboration (e.g. Dempsey, 2010), the focus of this paper is on the oftenneglected element in the debate on impact, namely the working practices of those employed as academic researchers in universities.

Following a review of recent literature on employment in universities, the paper discusses these and related questions by reporting the results of semi-structured interviews with thirteen academic researchers with an interest in sustainable tourism working in British universities. As others have argued, the UK context is a valuable starting point for understanding the consequences of promoting impact because it has become so ingrained in the assessment of research performance (see, for example, Brauer, Dymitrow \& Tribe, 2019; Phillips, Page \& Sebu 2020).

It is judicious to note at the outset that the paper does not evaluate the extent to which academics make an impact on non-academic practice, other than tangentially or by inference. Several studies have already examined the scale, scope and dynamics of research impact in tourism (e.g. Brauer et al., 2019; Melissen \& Koens, 2015; Phillips et al., 2020; Ruhanen, 2008; Thomas, 2012; Thomas, \& Ormerod, 2017; Thomas, 2018). Most suggest that claims to impact are exaggerated; this is not surprising because they usually occur in the context of research performance evaluations that are tied to funding.

The most prevalent reasons offered for the reported limits to impact are noteworthy for their simplicity, with commentators tending to emphasise various forms of market failure (for a recent example, see Jorgensen \& McKercher, 2019). These interpretations are unconvincing because they conflict with well-established bodies of theoretical and empirical literature. It seems that those theorising innovation in commercial tourism, for example, do not identify a role for academic work in their explanatory schema. Similarly, academic research on tourism policy formation and change, and on tourist behaviour change, do not include academics in their interpretations (Thomas, 2018). It is improbable, therefore, even by our own accounts, that impact beyond academia is likely to be substantial (or we need to re-theorise much of the tourism literature).

Several commentators have suggested an over-reliance on conceptualisations of knowledge production which privileges universities and, arguably, limits insight into the organisational and social worlds that they seek to illuminate (Van de Ven, 2007). Drawing on notions of shared knowledge production, several researchers in tourism have instigated creative approaches to collaborative research (e.g. Cockburn-Wooten, McIntosh, Smith and Jefferies, 2018; Duxbury, Bakas \& de Carvalho, 2019; Schweinsberg et al., 2018). Their positive reporting of experiences suggests that much is to be gained by academics who aspire to effect changes in policies or practices from adopting these methodologies and methods. It is noteworthy, that while recognising practical difficulties, these contributors do not resist the essence of neoliberal research policy goals but promote alternative ways of securing their achievement (cf. Phillips, Page \& Sebu, 2020).

\section{Academic work in neoliberal universities}

There is an appreciable literature now available on the nature of work in contemporary universities. Much of it is critical with an emphasis on the employment effects of transformations to the global university landscape over recent decades. The most pronounced changes relate to the significant 
growth in participation rates (Tight, 2019), marketisation (Watts, 2017), international competition, branding and rankings (Yudkevich et al., 2016), and regular assessment of performance (Sayer, 2015; Wilsdon, 2016).

Changes manifest in higher education policy simply reflect wider politico-economic developments. Somewhat imprecisely, these are usually labelled 'neoliberal' (Peck and Tickell, 2007) and, in terms of public management, utilise a battery of metrics to measure performance (Redden, 2019). Its essence is operationalised in universities via a coherent discourse that draws upon a commercial logic blended with orientations that emphasise the need to contribute to national economic and other welfare goals (Smyth, 2017). From this perspective, students should expect an education that they rate highly and, subsequently, gain from in terms of higher paid employment. A demand that publicly funded research should result not only in high quality outputs (usually measured by citation metrics and journal rankings) but also generate non-academic impact is entirely congruent with such a discourse and is an obvious corollary (Brown and Carasso, 2015; Stern, 2016).

Although the missions of contemporary universities vary significantly, it remains apposite to consider employment within the sector collectively. Notwithstanding contrasting contextual constrains and opportunities, management interventions have not differed significantly; as one commentator recently noted, they draw on a relatively narrow range of identifiable options (Watts, 2017).

\section{Performativity, affective subjectivation and precarity}

One of the most prominent themes to emerge in the literature on work in higher education is that of 'performativity' (Clarke and Knights, 2015; Macfarlane, 2016; Smyth, 2017). As Ball (2012: 19) notes: (performativity is) a powerful and insidious policy technology that ... links effort, values, purposes and self-understanding to measures and comparisons of output .... In regimes of performativity experience is nothing, productivity is everything. Last year's efforts are a benchmark for improvement - more publications, more research grants, more students. We must keep up; strive to achieve the new and very more diverse targets which we set for ourselves in appraisal meetings; confess and confront our weaknesses; undertake appropriate and value-enhancing professional development; and take up opportunities for making ourselves more productive .... We take responsibility for working hard, faster and better as part of our sense of personal worth and the worth of others.

The consequences are manifold. Academic work requires what (Page, 2020) alludes to as 'conspicuous practice'; the public display of activity and achievement. Perhaps somewhat paradoxically for a sector that often claims collegiality as a core value, the neoliberal university has led to what Ryan (2012) has termed hyper-individualism. The transparency of metrics and their apparent neutrality enables clear comparison to be made between individuals. The juxtaposition of encouragement to self-aggrandizement by the lure of potential career-advancement also leads to a more commonly shared sense of under-achievement and failure (Clarke and Knights, 2015). This fear of failure is often exploited; the affect of anxiety is widespread and linked to insufficiency and to precarity (Brunila and Valero, 2018). Valero, Jorgensen and Brunila (2018: 136) adopt the term 'affective subjectivation' to label these processes that cause academics to conceive of themselves as 'manageable subjects' within this context. As they argue:

Nowadays the neoliberal (university) ethos is embodied in the doings, actions and emotions of the people involved in everyday work in universities. It is instantiated in how researchers and research institutions generate and operate through a constant ambivalence between, on one hand, an affect of anxiety, insufficiency, competitive 
entrepreneurship, and violence, and on the other hand, an affect of positive optimism, self-improvement, and contempt. It is in the constant interplay of these ambivalences that mechanisms for effecting precarious neoliberal subjectivities are to be found.

The need to perform and to overcome precarity leads to a distortion of ethical practice. Some is fraudulent (Koczela, Furlong, McCarthy and Mushtaq, 2015) but in other cases it leads to a selfcensorship and a reluctance to question the agenda of powerful actors (Lo Piccolo and Thomas, 2008; Thomas, 2011). To many, but by no means all, these developments are 'toxic' (Smyth, 2017) and deleterious to collegiality, 'good education' and research (Docherty, 2015).

Brunila and Valero (2018: 74) suggest that affective subjectivation might be challenged by revealing the 'public secret of governing through affect' leading academic researchers to imagine new possibilities for resistance and engagement in more meaningful academic work. Other critics discuss 'anti-performativity' (a rejection of knowledge production to further the interests of elites) (Fournier and Grey, 2000) and progressive (Wickert and Schaefer, 2015) or critical performativity (the use of research to support subversive voices) (Spicer et al. 2009; 2016). The authors are less clear about how such changes will occur.

Hales, Dredge, Higgins-Desbiolles \& Jamal (2018) are among the few academic researchers in tourism to have written on this topic. They argue that there are four ways that academics might resist affective subjectivation and gain impact. First, they may challenge dominant discourses by producing knowledge that they disseminate via publications, conferences or through teaching.

Secondly, they suggest that a voice may emerge from universities that encourages change elsewhere. Access to the public as a result to their work as an academic may act as a third way of influencing others and, finally, academics may join bodies, from professional associations to activist groups, and gain impact via those channels. The role these activities may play in academic identity construction, especially as part of resistance strategies to affective subjectivation, is unmistakeable. Indeed, the paper is most valuable for its insights into the meanings these actors ascribe to their actions as academic activists, to the values that underpin them and to the personal challenges faced within their own institutions as they sought to support those with little power. As they state (Hales et al., 2018: 194):

All four authors are strongly concerned that their service is directed to other communities of interest beyond industry, communities that are typically confronting the ecological, sociological, and/or cultural impacts resulting from the consequences of tourism development but whose voices are marginalised or overlooked in development discourses. Far from being antitourism, the authors are unanimous in their support for the positive world-making benefits of tourism.... Each author has experienced tensions in meeting the performance measures and approval of university managers as they have tried to be of service outside the academy (for the public good).

For some, this will represent a refreshing departure from the narratives Dashper and Fletcher (2019) identify in the field of events management. Their reading of participants' testimony suggests that advocates of critical events studies have gained little traction in terms of anything more than the first of Hales et al.'s (2018) categories of impact. Indeed, even then it did not appear as part of the narratives identified. Their suggestion, instead, is that academic colleagues in that field are either concerned with industry engagement and gain legitimacy based on their knowledge and experience 
of practice or emphasise their academic work to justify their position. Either way, not one of the three narrative types described included any element of non-academic impact via research.

\section{A comment on moral framing}

The literature on sustainable tourism often adopts an explicitly normative position in terms of how tourists and organisations associated with the activity should articulate with the environment, local communities and others. Even where this is less evident, the discourses from which academics draw and to which they contribute are not neutral; they are used to promote value-laden views of the world (Ketola, 2008). Since '...moral values affect both private actions and collective action within the public sphere....' (Adger et al., 2017: 374), it is instructive to consider whether such moral values inform the deliberations on research impact of those researching sustainable tourism.

Several commentators have suggested frameworks for examining the issues actors identify as worthy of moral scrutiny and how they engage in moral reasoning. Kreps and Monin (2011), for example, draw a distinction between private and public moralization, suggesting four possible combinations: full moralization (an individual takes a moral position in public and in private); no moralization (there is an alignment of public and private action but this time in rejecting the issue as being of moral relevance); private moralization only or moral muteness (where there may be social organisational norms or pressures undermining declarations on certain issues in moral terms); public moralisation only or playing to the moral crowd (where there is a mismatch when actors frame the issue morally in public, perhaps to conform with a perceived consensus, while privately taking an alternative or pragmatic view).

Thomas (2015) used Kreps and Monin's framework to interrogate the sustainability practices of small firms in tourism. In addition to finding instances of each, his discussion highlighted potential personal advantages (in this case to owner-managers) and potentially negative consequences of adopting particular positions. This approach to examining the dispositions and actions of academic researchers towards impact on sustainable tourism might yield additional, and more nuanced, insight. Without wishing to anticipate what is to follow, it is striking that a recent study of air travel behaviour among academics found little difference between the behaviours of those termed 'green' and 'non-green' researchers (Wynes et al., 2019).

As a development to the idea of moral hypocrisy, Lindenberg et al. (2018) recently proposed a theory of hedonic hypocrisy. Moral hypocrisy is equated with pragmatic hypocrisy, whereby an insincere commitment is declared for personal advantage (perhaps under pressure from a wider group norm). Hedonic hypocrisy is different:

The theory ... is that people like to feel moral concerning their own moral norms. They act morally when they are confronted with clear choices regarding 'right' or 'wrong', but exploit any ambiguity or flexibility regarding what is right or wrong to behave egotistically and interpret it in such a way that they still feel moral.... It points to the important role of feeling moral (not just appearing moral ... )... (Lindenberg et al., 2018: 395).

Although others have questioned how the theory might be operationalised effectively for the purposes of empirical research (Przepiorka, 2019), there is merit in identifying the potential for tension between academic rhetoric and action when exploring issues of research impact (action). Higham and Font (2020: 1) endorsed such a perspective recently when they called for academics to confront what they term 'climate hypocrisy' and to 'show leadership... by auditing our own impacts, reducing them.....and not just reporting how unsustainable everyone else's behaviour is'. 


\section{Research design and methods}

The research investigated how academic researchers working in the area of sustainable tourism were responding to the (non-academic) impact agenda. It is important to emphasise that the unit of analysis was not tourism scholars in general; arguably, little unites that community other than their interest in an aspect of a social phenomenon (tourism). By contrast, sustainable tourism researchers moralise tourism, as was illustrated earlier by reference to the editorial policy of this journal (Font, Higham, Miller \& Pourfakhimi, 2019). This suggests that official judgments on the value of research that encompass impact would, prima facie at least, resonate with a constituency of scholars who aspire to connect their research with social, economic or environmental improvement.

The study's first methodological challenge was to identify participants from the sub-field of sustainable tourism who were engaging in rigorous research, a prerequisite to achieving impact via research. A population of 111 academics who were submitted as part of a cluster of tourism researchers to the most recent national assessment of research quality and impact (the Research Excellence Framework, 2014) were deemed to qualify as being engaged in rigorous research. Each of these had been nominated for assessment because they had produced work of sufficient 'originality, significance and rigour', as judged by their own institution.

To be selected as a researcher in the sub-field of sustainable tourism, participants had to meet at least one of the following criteria: they had published in this journal or had published at least two articles that had 'sustainable tourism' or related terms (e.g. sustainable development and tourism) in the title (or keywords) or had published at least two articles on topics that resonated with the editorial remit of JoST e.g. environment, poverty alleviation, or social tourism. The latter category was included so that there were sufficient numbers of participants to allow for a meaningful investigation yet enabled the assurances given about anonymity to be met. Not to have done so would have increased significantly the likelihood of participants being identified. This was not a perfunctory exercise; there were potentially negative employment or career consequences for those identified, for example, as adopting a critical or subversive position on this activity.

Data were garnered via semi-structured interviews with thirteen academic researchers based in British universities. The sample comprised eight male and five female participants of varying seniority. The sample was skewed towards those working in larger established departments or schools of tourism because that is where most researchers submitted for REF 2014 were employed. The participants were not statistically representative of academic researchers with an interest in sustainable tourism in the UK or elsewhere in the world. Nevertheless, the data provided insights that enable the debate about academic impact to advance in a new direction; from providing guidance on how to achieve and measure impact (e.g. Denicolo, 2014; Reed, 2016) to the practices of academics from a sub-field that might be well disposed towards it.

Each interview explored attitudes to impact and how individual practices were influenced by this dimension of research policy. Data analysis identified prominent themes, nuances of the rationales for (in)action, and sought to assess their significance to the working lives of academic researchers.

As a senior researcher working at a well-established school, I knew, to varying degrees, most of those I interviewed. I was concerned to exclude prior knowledge and to listen carefully to the contemporary accounts given. As someone who has written about an aspect of this topic (Thomas, 2012, 2018; Thomas \& Ormerod, 2017), I was particularly mindful to avoid imposing my perspective on the data. To help guard against this, I engaged in a process of 'reading back' to participants what 
I understood they were telling me. This resulted in refinements to my notes and the subsequent transcripts. Inevitably, there remains the possibility of some degree of misinterpretation.

\section{Framing research impact}

Although enthusiasm for the policy emphasis on non-academic impact varied significantly, none of those interviewed were critical of the idea in principle. In other words, they considered it a reasonable expectation that their research should inform policy and practice beyond academia:

If you had asked me 10 years ago, I would have said no, but increasingly I do think it matters. I do think we need to have more impact (R9)

It is partly the pressure to demonstrate that you've got an impact .... I mean, that is important. Increasingly, I'm aware of my own sense that research for the library shelf is not enough...(R4)

The language used points to shifts in outlook that mirror the expectations of others, notably those evaluating research performance. Some identified tensions between what they saw as academic research and research that was likely to have non-academic impact; between what was 'theoretical' and that which would be of practical value (apparently leading to impact). This dichotomy tended to be seen as axiomatic:

It (official assessment of research) is designed with a certain kind of research in mind ... Which does not work for us at all, it is pointless. But there we are, we're stuck with it. You have to be pragmatic on one side, but still be true to your research aims on the other. So it is a matter of working out a way in which you can get them to coincide and not compete (R4)

I think, and just accept that if people think that ... publishing something that's a bit more theoretical means something ...(it) legitimises me in the academic community ... And then there is doing something that has practical value ...(R8)

Research of 'practical value' was usually described in terms associated with consultancy; it was generally seen as 'routine' with immediate usability for interested actors. Typically, such research would be atheoretcial and involve providing an evidence gathering service, for example via surveys or case studies, and based on specific needs. Participants acknowledged low levels of engagement in this kind of research because of the competing demands on their time and, for some, its limited intellectual appeal.

One of the most striking insights from the interviews was the modest incidence of moralising research impact; for most there was little connection between their research (usually defined in terms of publications) and what it might lead to or achieve for others. Some made connections between their aspiration for a 'better' world, enabled by tourism or a 'better tourism'. Most of these researchers were, usually by their own admission, unsophisticated in their conceptualisation of research impact. Perhaps not surprisingly, they made few claims about effecting change among non-academic audiences:

I think for me, as someone who's kind of a social scientist who thinks of trying to change the world, trying to make it more ethical and less driven by profit, I think I am on a hiding to nothing ...(but) I do try (R3). 
I sometimes get disappointed and have a sense of there's nothing we can do... but at least I can raise awareness even if it's only in a certain context (for academic audiences via journals) (R13).

There was one conspicuous exception. The ethical protocol produced for this project would be compromised if a detailed explanation were offered here. The following passage illustrates, however, the deliberate focusing on research informed by the researcher's values and intention to effect social improvement via tourism by working with other (non-academic) actors:

So say, for example, the research that I did with XXXXX, it had an impact on them. Categorically. My relationship with them to the research that we did right at the very early stages through to XXXX, which was an important time in (their)... history and development. And what's happened subsequently, definitely it's had an impact... There's (now) a XXXX movement. I remember sitting down in the meeting ... and coming up with that ... We were all there sitting round, saying 'What we've got to do now with the research is to actually demonstrate that it's of relevance to people, that we can do something with it that will help transform the way that they think about XXXX tourism. That's the way we did it. We weren't using the language of impact. The impact agenda wasn't really, you know, clearly worked out there. It was something that we knew that we wanted to do as a consequence of the research.... What we'd found out about ... weren't just going to be important for XXXX. That we had to make a broader case for it. So yes. And we know that it transformed XXXX, because they changed ... But actually that ... that's something that I really feel passionate about ... This is something that I do because I really feel strongly about it, regardless of what the impact is (as measured by others)... (R1)

There was extensive evidence of concerns with social justice as a driver for the topics that individuals elected to research and it is possible that the moralising of impact was implicit for the participants in this study. Probing and prompting during interviews, however, did not yield evidence suggestive of this. Instead, it exposed manifold links with practitioners and policymakers but its framing was usually related to notions of performativity, such as those required for research assessment exercises, grant applications or to promote security of employment and career enhancement. Several were sceptical about their own impact and of others:

They say 'we work towards poverty reduction' but we've been working there (country X) for ten years. What has changed? To get back to impact, nothing (R7)

This observation and others like it implies a rejection, or an unawareness, of the burgeoning literature on approaches to knowledge construction that articulate with ideas of impact advocated by commentators such as Van de Ven (2007) and more latterly by tourism scholars such as Cockburn-Wooten et al. (2018) and Duxbury et al. (2019). No connection was made between ontologies and epistemologies that would envelope aspirations for impact with ease by, for example, engaging in participative approaches to research and co-creating knowledge with practitioners and policymakers. Moreover, participants were evidently not influenced by those who have argued that academic researchers will remain emasculated if they maintain an adherence to processes of knowledge production that dominate western university systems. Indeed, the interviews revealed widespread unfamiliarity with debates on critical or anti-performativity that are taking place in allied fields or disciplines (e.g. Gond et al, 2015; Wickert and Schaefer, 2015; Spicer et al., 2016) notwithstanding the unifying emphasis on tourism as a potentially liberating phenomenon (though conceptualised and articulated in very different ways). Instead, the picture that emerges is one of compliant participants who either flounder when invited to explain their approach to impact or create narratives that draw mainly on routine applied research. 


\section{The need to get results (with sustainable tourism pushed to the background)}

It would be misleading to suggest that participants made positive associations between their research and non-academic impact in terms that simply emphasised benefits to themselves. Nevertheless, almost all drew more upon the language of neoliberal research policy than that of sustainable development. Thus, participants usually framed their work in performative terms:

Well I am thinking about it, it's there all the time, in different ways. You know, if you're engaging in research then you need to be engaging in impact. The bid that I just submitted had a big section on impact. You have to think about impact. You do have to build impact into a case for research... (R12)

That was well-received here in the university, I was a finalist for their XXXX awards. They loved it ... (R1)

I do feel pressure to achieve impact through the REF... it's such a competitive landscape and impact seems to be becoming central to what we do... but much less achievable than we think.. (R2)

So, I think that largely it's brought a lot of stress to people who've got enough pressure to deal with already. (R7)

To that extent, the interviews replicated aspects of the kind of individualism and careerism reported by Clarke and Knights (2015). Senses of 'excellence' and 'meritocracy' were tied up with selfaggrandisement or personal failure; this was applied to impact as well as to other aspects of what an academic researcher was expected to achieve:

.. And my worry is that a lot of the people that are against the whole idea of doing purposeful research ... They want to keep working in their ivory tower and nobody ever asking them for being accountable for their time... (R10)

Not everyone tries. That is up to them. Impact does not just happen. You have to work at it, spend time with people and sell them the idea that we have something to show them. Because people don't, that is why not many of us have the respect of industry. (R6)

An antipathy to dissenting voices, leading to an 'othering' of colleagues, also featured:

This is now a team game. It has to be about our coherence and not the ramblings of mavericks, however good they are or think they are. We need to make a difference and to shout about it.(R6)

And I think the problem is we have earned ourselves a reputation ... that what we do is too slow, too little, too irrelevant, too conceptual, and does not really provide something to industry that they can work with. Our timeframes are completely different. The way in which we work is different. They will ask us for a piece of work and our answer is 'Let me go and do a literature review about that and then in four months' time l'll get an ethics form written up. And maybe in a year's time I can give you some preliminary results.' No. No, I do not think so.... (R8) 
As a consequence, strategies became more about demonstrating impact that was recognised as valuable by research policymakers than related to even loose conceptions of sustainable tourism.

Well, I think there are games that you have to play... so I just have to be pragmatic... (R1)

I would say (I have been) relatively successful (at achieving impact) but I have not been very good at collecting data or evidence of that... (R8)

Several remarks suggest a degree of hedonic or moral hypocrisy; often participants were keen to do good but also to celebrate their achievements very publicly for one of two purposes (or both).

Firstly, to be seen as moral academics keen to make the world a better place. Secondly, to enhance their credentials for career purposes (which usually necessitated measurement of impact and its presentation to others). The hint a moral hypocrisy relates to the rationalisation, but only on prompting, of contradictory aspects of their behaviour. The most notable of these were the little commented upon tension between narratives of impact and induced carbon emission usually via long-haul air travel, and ideas of colonised research interventions where privileged researchers speak for (or to) the disadvantaged.

\section{The non-issues}

It is now well understood that what is not discussed by participants during interviews may be as revealing as what is (e.g. King, Horrocks \& Brooks, 2019). Three issues that were only discussed on probing and prompting are worthy of note in this respect. Collectively, they endorse a perspective of research impact being conceived mainly in performative terms rather than as a means of legitimising researcher interventions to strengthen sustainable tourism.

The first 'non-issue' is participants' almost entire lack of (articulated) concern with climate change in relation to researcher behaviour. Several, somewhat uncomfortably on prompting, appeared to suffer degrees of what Mkono \& Hughes (2020) term 'eco-guilt' and 'eco-shame'; they acknowledged inconsistencies between their own behaviour and what they espoused as values. As one frequent flyer stated: 'I do sometimes feel guilty for flying so much'. Others rationalised their actions in this respect by pointing to a range of benefits gained from the insights they provided to international partners via particular projects or represented international travel as an important dimension of building personal networks. By way of illustration, one noted the strength of an international collaboration between their university and an NGO in a developing country. It had apparently led to the creation of an attraction that met the criteria for being 'good practice' in terms of sustainable development; high carbon emissions were justified in this way and alternative ways of working had been considered but rejected. There was an acknowledgement, on probing, that the persuasiveness (impact) of academics was influenced by their own behaviour (Attari, Krantz \& Weber, 2016; Anderson, 2013) but this was insufficient motivation to alter working practices. Regarding the building of networks for professional purposes, none of the participants were familiar with studies that challenge the veracity of claims made linking travel with research productivity (see for example, Wynes, Donner, Tannason \& Nabors, 2019) or were particularly enthusiastic to consider the question. For these academic researchers, personal networks represented important dimensions of career advancement strategies and were separated from issues of sustainable tourism. To a large extent, they typified the rationales for behaviours that have been subjected to intense criticism by the editors of this journal (Higham and Font, 2020).

Although not common, it is revealing that issues of collective performativity also transcended environmental and other concerns where they were expressed. As one participant noted: 
...all the good projects about environmental impact, poverty...there was no space for critical discussion. I didn't think this was welcomed. It's not that people said we don't want to hear what you have to say but ... at least that's how I felt. (R5)

The second striking omission until prompted was the almost complete absence of critical discussion associated with notions of decolonising research or challenging ideas of intervention that suggested a western hegemony (Alcoff, 1991; Tuhiwai Smith, 1999; Bhambra, Gebrial \& Nişancıoğlu, 2018). There was one exception and she talked about her discomfort in the following manner:

We get together and praise ourselves ... and it's great that we are all together working on the same issues and fighting for the same causes ... but this group of people is almost ....very much western perspective, privileged people very often ... The culture was one that said this is what we do here and once you said that you can't necessarily contribute to that from a western perspective, or said it's not always appropriate, ... it was not welcome.... Being critical is equated with being negative or being detached ... (R11)

Others, however, were apparently entirely unaware of this being a potentially important critique. Instead, they spoke of working in former British colonies to support tourism development with no hint that this could be interpreted as anything other than benign.

The final 'non-issue' relates to the absence of students from the narratives of impact offered by participants. For some, perhaps most, this was probably because research performance evaluations generally classify the education of students as an academic rather than a non-academic impact. In that sense, such impacts would have been beyond the scope of the research project to which participants were contributing. One participant claimed impact from non-accredited courses:

... they (practitioners) see things differently as a result of attending my courses. More attending my courses than reading my work, in truth... And a number of people say to me "I get a real sense of satisfaction of coming back to your course, hearing some of the same advice and being able to say yes, I have done that because I was here last time, and here's some of the things he's saying now that I haven't changed yet, and I'll go back and do it now." That's just such an amazing adrenaline (sic). (R8)

Even on prompting, however, there was little sense of a coherent conceptualisation of teaching that was linked to the attainment of sustainable development via tourism. In other words, the moral imperatives associated with sustainable tourism were not seen in terms of changing behaviour via teaching any more than gaining impact via other means.

The nearest to a perspicuous account of how research on sustainable tourism effected change via the education of students was described by one participant in historic terms. There was a period in the recent past when the alumni of a particular degree course were seen as part of a social movement. Their apparently shared understanding of the dynamics of tourism, notably where it could be a force for social improvement, and how past students might effect change from within organisations was considered to be an important development that became stymied by changes of personnel (academic staff leaving and new appointments to managerial positions that did not share this perspective). There were no similarly contemporary accounts offered.

\section{Conclusion}


The findings reported in this paper suggest that academic researchers with an interest in sustainable tourism are currently concerned mainly with their own performativity. They are sensitive to the growing official expectation for non-academic as well as academic impact and are generally sympathetic to this policy goal. This is not surprising: it would have been curious had those whose research was intertwined with particular values were not interested in effecting changes in public policies or private practices. Conceptualisations of the processes leading to impact and narratives of impact were, however, generally crude. Participants often 'recognised' their own 'failures' in this respect or pointed to the failures of others as explanations for limited impact. None described their approach using language associated with anti- or progressive performativity (e.g. Fournier and Grey, 2000; Wickert and Schaefer, 2015). Perhaps as a consequence, there were no convincing accounts of identity construction ingrained with ideas of academic activism as have been articulated elsewhere (Hales et al., 2018).

The prevailing disposition towards impact appears to be driven mainly by neoliberal university management practices that arise from contemporary public (research) policy. Widespread affective subjectivation, in turn, provides a plausible explanation for current academic behaviour. To that extent, the way participants in this study discussed their work was not significantly different from tourism scholars whose research interests extended beyond sustainable tourism or from academic researchers working in other disciplines and fields of study (Thomas, 2018).

The limited moral framing of research impact in relation to sustainable tourism, and the potential for moral hypocrisy, need not imply a comprehensive lack of sincerity among participants. For some, their public moralising might have collided with elements of hyper-individualist and careerist behaviours; in other words, they were able to make connections between what would be highly regarded and helpful for their careers. For most, however, limited consideration had been given to how their research work might contribute to a more sustainable tourism (whatever that meant to them).

This journal declares connections between research and advocacy for the promotion of sustainable tourism. To advance this agenda, it assembles high quality special issues on pertinent themes and encourages some consideration of research implications for policy and practice. What is less clear, however, is its position on accepting research papers that reflect ontological and epistemological positions which sit comfortably with aspirations for impact (e.g. Van de Ven, 2007). A special issue on how 'engaged scholarship' might yield shifts in practice would be a useful starting point in this respect. Consideration of novel forms of dissemination and collaboration with practitioners and policy-makers might also precipitate actions to encourage impact. Without such leadership and a collective re-thinking of how academic research might gain influence beyond academia, it is probable that the performative practices encapsulated by the vignettes at the beginning of this paper will continue to characterise academic responses to the impact agenda.

\section{References}

Adger, N. W., Butler, C. \& Walker-Springett, K. (2017) Moral reasoning in adaptation to climate change. Environmental Politics, 26(3): 371-390.

Airey, D., Tribe, J. and Benckendorff, P. (2015). The managerial gaze: The long tail of tourism education and research. Journal of Travel Research, 54(2): $139-151$.

Alcoff, Linda (1991). The problem of speaking for others. Cultural Critique, 20, 5-32. 
Anderson, K. (2013). Hypocrites in the air: should climate change academics lead by example?

Attari, S. Z., Krantz, D.H. \& Weber, E.U. (2016). Statements about climate researchers' carbon footprints affect their credibility and the impact of their advice. Climatic Change, 138(1/2): 325-338.

Bhambra, G.K., Gebrial, D. \& Nişancıoğlu, K. (Eds.) (2018). Decolonising the University. London: Pluto Press.

Ball, S.J. (2012). Performativity, commodification and commitment: An i-spy guide to the neoliberal university. British Journal of Educational Studies, 60(1): 17-28.

Bastow, S., Dunleavy, P. \& Tinkler, J. (2014). The impact of the social sciences. London: Sage.

Bramwell, B. \&Lane, B. (2002). The journal of Sustainable Tourism: The first ten years. The Journal of Sustainable Tourism, 19(1): 1-4.

Bramwell, B., Higham, J,, Lane, B. \& Miller, G. (2016). Advocacy or neutrality? Disseminating research findings and driving change toward sustainable tourism in a fast changing world. Journal of Sustainable Tourism, 24 (1): $1-7$.

Brauer, R., Dymitrow, M. \& Tribe, J. (2019). The impact of tourism research. Annals of Tourism Research. 77: 64-78.

Brown, R. and Carassso, H. (2015). Everything for sale? The marketization of UK higher education. Abingdon: Routledge.

Brunila, K. \& Valero, P. (2018). Anxiety and the making of research(ing) subjects in neoliberal academia. Subjectivity, 11: 74-89.

Clarke, C.A. and Knights, D. (2015). Careering through academia: Securing identities or engaging ethical subjectivities? Human Relations, 68(12): 1865-1888.

Cockburn-Wooten,, C., McIntosh, A.J., Smith, K. and Jefferies, S. (2018). Communicating across tourism silos for inclusive sustainable partnerships. Journal of Sustainable Tourism, 26(9): 14831498.

Dashper, K. and Fletcher, T. (2019). 'Don't call me an academic': Professional identity and struggles for legitimacy within the vocational field of events management. Journal of Hospitality, Leisure, Sport \& Tourism Education.

Denicolo, P. (Ed.) (2014). Achieving impact in research. London: Sage.

Docherty, T. (2015). Universities at war. London: Sage.

Duxbury, N., Bakas, F.E. \& de Carvalho, C.P. (2019). Why is research-practice collaboration so challenging to achieve? A creative tourism experiment. Tourism Geographies.

Font, X., Highham, J., Miller, G. \& Pourfakhimi, S. (2019). Editiorial: Research engagement, impact and sustainable tourism. The Journal of Sustainable Tourism, online. 
Fournier, V. and Grey, C. (2000). At the critical moment: Conditions and prospects for critical management studies. Human Relations, 53(1): $7-32$.

Hales, R., Dredge, D., Higgins-Desbiolles, F. \& Jamal, T. (2018). Academic activism in tourism studies: Critical narratives from four researchers. Tourism Analysis, 23, $189-199$.

Higham, J. \& Font, X. (2020). Decarbonising academic: confronting our climate hypocrisy. Journal of Sustainable Tourism. 2028 (1): $1-9$.

King, N., Horrocks, C. \& Brooks, J. (2019). Interviews in qualitative research. London: Sage.

Ketola, T. (2008). A holistic corporate responsibility model: integrating values, discourses and action. Journal of Business Ethics, 80: 419 -435.

Koczela, Stevea; Furlong, Cathyb, McCarthy, Jakic,and Mushtaq, Alid (2015). Curbstoning and beyond: Confronting data fabrication in survey research. Statistical Journal of the IAOS (International Association for Official Statistics), 31(3): 413-422.

Kreps, T.A. \& Monin, B. (2011). 'Doing well by doing good?' Ambivalent moral framing in organizations. Research in Organizational Behaviour, 31, 99 -123.

Lindenberg, S., Steg., Milovanovic, M. and Schipper, A. (2018). Moral hypocrisy and the hedonic shift: A goal-framing approach. Rationality and Society, 30(4): 393-419.

Lo Piccolo and Thomas, H. (2008). Research ethics in planning: a framework for discussion. Planning Theory, 7(1): $7-23$.

Macfarlane, B. (2016). From identity to identities: a story of fragmentation. Higher Education Research \& Development, 35(5): 1083-1085.

Melissen, F. \& Koens, K. (2016) Adding researchers' behaviour to the research agenda: bridging the science-policy gap in sustainable tourism mobility, Journal of Sustainable Tourism, 24:3, 335-349.

Mkono, M. \& Hughes, K. (2020). Eco-guilt and eco-shame in tourism consumption contexts: understanding the triggers and responses. Journal of Sustainable Tourism, doi.org/10.1080/09669582.2020.1730388

Page, D. (2020). The academic as consumed and consumer. Journal of Education Policy.

Phillips, P.A., Page, S.J. \& Sebu, J. (2020). Achieving research impact in tourism: Modelling and evaluating outcomes from the UK's Research Excellence Framework. Tourism Management, 78: 104072.

Peck, J. and Tickell, A. (2007). Conceptualising neoliberalism, thinking Thatcherism. In Leitner, J., Peck, J. and Sheppard, E. (Eds.) Contesting neoliberalism: Urban frontiers. New York: Guildford Press, $26-50$.

Przepiorka, W. (2019). No evidence for hedonic shifts to bring about more moral hypocrisy: A comment on Lindenberg et al. (2018). Rationality and Society. 31(3): 354-360.

Reed, M.S. (2016). The research impact handbook. Fast Track Impact: Aberdeenshire. 
Redden, G. (2019). Questioning performance measurement. Metrics, organisations and power. London: Sage.

Ruhanen, L (2008) Progressing the sustainability debate: A knowledge management approach to sustainable tourism planning. Current Issues in Tourism. 11(5): 429 - 455.

Sayer, D. (2015). Rank hypocrisies. The insult of the REF. London; Sage.

Schweinsberg, S., Heizmann, H., Darcy, S., Wearing, S. \& Djolic, M. (2018). Establishing academic leadership praxis in sustainable tourism: lessons from the past and bridges to the future. Journal of Sustainable Tourism. 26 (9): 1577-1586.

Smyth, J. (2017). The toxic university: Zombie leadership, academic rock stars, and neoliberal ideology. London: Palgrave Macmillan.

Spicer, A., Alvesson, M. and Karreman, D. (2009). Critical performativity: the unfinished business of critical management studies. Human Relations, 62: 537 - 560.

Spicer, A., Alvesson, M. and Karreman, D. (2016). Extending critical performativity. Human Relations, 69(2): $225-249$.

Stern, Lord N. (2016). Building on success and learning from experience. An independent review of the Research Excellence Framework. London: Department for Business, Energy and Industrial Strategy.

Thomas, R (2011) Academics as policy-makers: (Not) researching tourism and events policy from the inside. Current Issues in Tourism, 14(6): 493-506.

Thomas, R. (2012). Business elites, universities and knowledge transfer in tourism. Tourism Management, 33 (3), 553-561.

Thomas, R. (2015). Small firms and sustainable tourism policy: Exploring moral framing. In Gossling, S., Hall, C.M. \& Scott, D. (Eds.) The Routledge handbook of tourism and sustainability. London: Routledge, $397-406$.

Thomas, R. (2018). Questioning the assessment of research impact: Illusions, myths and marginal sectors. London: Palgrave Macmillan.

Thomas, R and Ormerod, N. (2017). The (almost) imperceptible impact of tourism research on policy and practice. Tourism Management, 62: 379-389.

Tight, M. (2019). Mass higher education and massification. Higher Education Policy. 32(1): 93-108.

Tuhiwai Smith, Linda (1999). Decolonizing Methodologies. London: Zed Books.

Valero, P., K.M. Jørgensen, and K. Brunila. (2018). Affective subjectivation in precarious neoliberal academia. In Resisting neoliberalism in higher education, volume I: Seeing through the cracks, ed. D. Bottrell, and C. Manathunga. New York: Palgrave, Springer. Pp 135 - 154.

Van de Ven, A.H. (2007). Engaged scholarship. A guide to organizational and social research. Oxford: Oxford University Press. 
Watts, R. (2017). Public universities, managerialism and the value of higher education. London: Palgrave Macmillan.

Wickert, C. and Schaefer, S.M. (2015). Towards a progressive understanding of performativity in critical management studies. Human Relations, 68(1): $107-130$.

Wilsdon, J. (2016). The metric tide. The independent review of the role of metrics in research assessment and management. London: Sage.

Wynes, S., Donner, S.D. Tannason, S \& Nabors, N. (2019). Academic air travel has a limited influence on professional success. Journal of Cleaner Production, 226: 959-967.

Yudkevich, Maria, Altbach, Philip, G. and Rumbley, Laura, E. (2016). The global academic rankings game. Changing institutional policy, practice and academic life. Abingdon: Routledge. 